\title{
Mythologeme-Related Crisis of Identity: Reality and Fictional Markers of Alienation
}

\author{
Svitlana Balinchenko
}

Ph.D., Yuriy Fedkovych Chernivtsi National University (Chernivtsi, Ukraine)

E-mail: sp.balinchenko@gmail.com

https://orcid.org/0000-0001-8345-0522

The paper observes some myth-triggered communicative distortions caused by mass-media distribution of common stereotypes of the Other. Another focal point of the article is the variety of possible mechanisms for overcoming the myths which emerged in the Ukrainian context of the hybrid war. The transformation from reality to counter-reality has been considered in terms of norm-oriented actions of an individual (with the focus of sameness and wholeness of self-concept connected to reality). The latter is opposed to the projected and split identity of the "dividuum" or Subiectum Neglegens textually involved in creating practical concepts and ignoring or eliminating counter-real mythologemes of Russian World and Split while being engaged in civic and political discourses. Thus, constructive and destructive ignoring has been evaluated according to the effect on the communicative actors: ignoring differences is compared with ignoring on the basis of differences in the social reality-forming legal texts. The normative changes resulted from the introduction of the practical concepts into the legislative field are observed from the perspective of the problem of internally displaced persons (IDPS) in Ukraine. This group of Ukrainians has been overcoming physical, legal and mental transposition from We-group to Other- or even Alien-group, and in some cases - to We-group again, as a result of an internal conflict of myth-based processes during the crisis identity shift.

Keywords: communication; mythologeme; internally displaced person; otherness; Other-group; Alien-group, Ukraine.

Received: November 5, 2018; accepted: December 12, 2018

Future Human Image, Volume 11, 2019: 5-13.

https://doi.org/10.29202/fhi/11/1

\section{Introduction}

The investigation has been focused on the otherness shifts involving counter-reality and reality markers, the latter regarded through the situation of displacement triggered by the Ukrainian context of the ongoing hybrid war.

The issue of reality, as opposed to counter-reality, can be traced to the studies on identity crisis by Erik Erikson, presented in Childhood and Society. The author connects the loss of sense of identity with lack of self-sameness evaluation of a subject. These self-

(C) Balinchenko, Svitlana, 2019 
identity contradictions are accompanied with generally sane personal identification. In his sociological analysis of psychic conflicts, Erik Erikson describes the acute problem of a person as that of what to believe in and what to become, as well as the indefiniteness of the intentions leading to identity crisis and disorientation as a result of self-idea failure or fragmentation [Erikson, 1951: 32-41]. The described shift from individuum (in terms of sameness and wholeness) to dividuum (a fragmented self) has had a great impact on various reality models of nowadays, them being substituted and compromised with virtual reality and counter-reality in social-cultural spheres prone to be faceted into sets of communicative influences and interchanges. The idea of data flows splitting singularities into the masses of variable and self-detached private fragments of information is presented in the work on dividuum, by Gerald Raunig, where the dividual singularities are regarded as able to be chained similar singularities, thus producing a specific subject different from individual model to [Raunig, 2015: 213-214].

Thus, the mythologemes actual in the situation under analysis, starting with rather archaic ones as those of Alien (it being applied to any unknown or misunderstood group representative) or Unity (exaggerated homogeneity of We-group), and up to the contemporary ones of Globality and Polarization, serve as counter-reality markers. The markers lack both links with the original situation of reality, and true-false evaluation, them being not simulacrumlike original-less copies or practical concepts, but rather performatives exploiting lacunas in social-cultural reality and having a linguistic-symbolic form of general intention-formative prescriptions. Thus organized components of similarity, in the perspective of Raunig's dividual similarities, are considered to lead to the shift from "Co-Formity" to "Multi-Formity" and "Form-Plurality" [Danner, 2015] through dispersion, rather than wholeness-seeking integrational process. Textual nature of mythologemes (the hybrid war actors mostly operate with the mythologemes of Russkii Mir (Russian World), screpy (religious-moral imperatives), Unity and Split) makes them easily distributed by means of mass-media and implemented in everyday communication where the imperatives and stereotypes become the triggers for aggression and exoticization of the Other.

Therefore, the investigation is aimed at defining the correlations between counterproductive mythologemes formed and spread in the informational space, on the one hand, and the practical concepts defining the situation and its participants through legislative and civic mechanisms. The otherness changes in the evaluation of the IDPs situation in Ukraine, for instance, is regarded through the amendments to the national legislation, the latter illustrating a gradual transformation shift under the pressure of the civil society, from considering IDPs as Alien-group to neutral Other-group, and further integration to the We-group of the host communities. Thus, one of the objectives is to analyze the practical concepts as opposed to the counterproductive informational models introduced by mass-media in order to distinguish identity speculations and their overcoming by means of changes being introduced into the collective discourse of the community.

\section{Materials and methods}

The notions of relation and responsibility can be viewed as indicating the reciprocal dissolving and separation processes of the codes of "proper" and "different" during interaction between societies and their withdrawal from the common space. The former code means the information that does not confront the stable cultural and social patterns of the society and the 
latter one denotes the means of preventing the unique features from mingling with those of the other society. Thus, the mythologemes of Unity and Split that emerge in the informational space are commonly positioned as orientation points for the society, and they can easily be used as a manipulation means in the modern post-truth form of war - a hybrid one. In the context of the hybrid war having been initiated by the Russian Federation in the Crimea and East of Ukraine, there has emerged the acute problem of political discourse concentration around the actors of the situation, which are interested in their status support or improvement by means of eliminating publicity from the decision-making process.

Therefore, the problem of political decisions affecting identity has been widely studied in the context of discourse ethics, as presented in the works by Vincent Descombes, Jürgen Habermas, Dietrich Böhler. The topic-relevant studies of conflict conditions leading, openly or implicitly, to identity transformation or crisis were conducted by Erik Erikson, Richard Rorty, Emmanuel Levinas and Ralf Dahrendorf.

The fading borderline dividing producers and consumers of information, as well as the voluntary formation of data streams between dividual (as opposed to individual) singularities, is addressed by Gerald Raunig in his "molecular versus molar" vision of machinic tendencies in capitalism. Moreover, the ethical dimensions of Other and altogether-Other are regarded in Badiou's critique of Levinas' approach to otherness, the dividuality of subjects thus gaining both additional crosslinks and limitations.

The communicative and value-based social changes in the unique Ukrainian contexts of borderline social transformation and war can be found in the works by Ukrainian researchers, among them, Yaroslav Liubyvyi, Vitalii Liakh, Liudmyla Sytnichenko, Kostiantyn Raida, Yevhen Bystrytskyi. The patterns and challenges of the hybrid war are regarded in the works by Oleg Bazaluk, Roman Dodonov, Vera Dodonova, Maryna Kolinko, Hryhorii Kovalskyi,

The unique situation of the hybrid war makes it possible to use legislation provisions and humanitarian missions' reports, with research purposes, as a source of practical concepts affecting the distribution of otherness in the situation, by means of defining the limits and normative grounds for We-group, Other- and Alien-groups of participants.

Therefore, the functional approach constitutes the methodological basis for the research and implies the practical concept of inner otherness compared with the members of the same social-cultural space being shifted to the Other-group to be regarded through the corresponding laws, case studies and official reports on IDPs (internally displaced persons) in Ukraine, the group being multiple (there are 1,7 million IDPs in Ukraine; based on the official reports of 2016) and socially vulnerable due to the conditions of otherness actualization.

\section{Individuum and dividuum ways of facing counter-reality}

Self-arranging of the things in reality into practically meaningful assemblies, rather than conjoining individuals within humanity, is viewed by Gerald Raunig as the basis for self-partition in the virtual social realities demanding a constant stream of self-fragmented information in the networks [Raunig, 2015: 149-152]. Quite similar to the felt-like patterns of knowledge produced in mosaics culture environment [Moles, 1969: 141], the self-like dividual singularities come into informational contact with the personal data "threads" while forming the general attitude and practical concepts of evaluations and reactions based on the accidental links emerging between informational fragments perceived, them becoming non-accidental through practical realization in communicative activities and law-making. 
The subject-oriented reality of individuum having been considered throughout Modernity implies true-false logical evaluations as a basis for reality-coding in language and culture. This idea of indivisible sameness leads, among other reality models to dualistic otherness of Wegroup (supposedly, positive and fair) and Other-/Alien-group (potentially false-intentioned and dangerous). The properly norm-structured self of individuum fits in the pre-made social niche of reality, it is constructed in accordance with social prescriptions and stable true-false stereotypes, them supporting the state of non-contradictory passive adaptation as needs are.

A previously mentioned shift from individuum to dividuum changes the role of contradiction. In his analysis of post-modern social-cultural tendencies, Vitalii Liakh states, that "the contemporary liquid reality vision implies systemic complexities, contradictions and mismatches as the problems to be resolved, rather than characteristics of reality" [Liakh, 2017: 7]. Thus, dividuum, as opposed to the individuum pattern of Modernity, becomes a constant never-ending tabula rasa [Raida, 2017: 99], the norms being substituted with changeable practical concepts emerging out of the liquid reality contradictory phases.

Therefore, there takes place a principal transposition of outer norms into inner contradictiontriggered practical concepts (We-group defence, dignity, freedom, tolerance and tolerating, ignoring differences, ignoring communicative actors on the basis of differences), the latter has the potential of becoming socially and politically significant if incorporated into the discourse field (for instance, as the Revolution of Dignity in Ukraine, November 2013 - February 2014). Here, in the reality versus counter-reality context, arises the mythologemical power of contradictions, in the cases when the prevailing traditional social and cultural patterns fail to be supported within the new discourse.

The crucial difference in the leading informational activities of reality-led individuum and counter-reality-led dividuum is that the former is prone to acquisition of information, it is regarded as a key resource; and the latter is to be focused on ignoring some clusters of information instead, the action requiring critical thinking and resource analysis, if ignoring is constructive. If the analysis fails and mythologemes substitute critically regarded vision of the situation, there is a risk of destructive ignoring, which implies that the situations are premodelled for recipients to have the reaction needed by the manipulative social-political actors. This change of the communication-defining activities from acquisition to ignoring turns a dividuum into a Subiectum Neglegens, thus affecting the whole range of spheres from lawmaking to mass-media flow analysis, in order to counteract fakes, as well as perlocutively risky information and evaluations.

\section{Conflict-reflecting mythologemes and identity problem}

In his evaluation of Russian aggression in Ukraine as a new type of conflict, a hybrid war, a Ukrainian philosopher Yevhen Bystrytskyi refers to the concept of cultural identity [Bystrytskyi, 2015: 61-74]. The combination of armed violence and communicative propaganda used in order to manipulate public opinion defines a hybrid war as a conflict arising from the attempts of legitimization of a projected identity being realized in objective actions.

National communities regarded as a sort of homogeneous Subject require the identity of values for all the members, perceived in the particular historical term. Thus, on the one hand, the aggressor state emerges in mass-media discourses as such, the virtual homogeneity annihilating diversity of opinions in the melting pots of enemy or victim concepts, as well as building up the grounds for the conflict escalation [Bystrytskyi, 2015: 63]. On the other hand, 
the patriotic impulse of defending the We-community lies beyond systemic institutions, it causing, for instance, an outburst of volunteering initiatives in Ukraine aimed at support and supply needed to counteract both violence and mass-media factual distortions.

The clash of two groups with the idea of We-group defense, the latter being similar but principally mismatching in social and political senses (Russian World versus Ukrainian community), focused at the same region considered an integral part of both identities; there outstands the problem of reality and counter-reality factors making this double-sided identity possible. The issue has been reflected in conflicting attitudes towards IDPs from Donetsk and Luhansk regions, them being considered the representatives of We-group and Other-group at the same time.

Transcendent nature of identity enables overcoming individual experience and having a wider perspective of an inner world being projected not into imagination only, but objective things, beings and actors. Yevhen Bystrytskyi stresses on the projective nature of identity in the sense of an imagined reality transformation into practical deeds [Bystrytskyi, 2015: 66]. It can be added that counter-reality of mythologemes implied in practice develops the same scenarios ranging from imagined to perceived through otherness projections, the objective actors being considered or presented as humanless or alien, for instance.

We-group values and expressed senses based on perception of We as opposed to the Other, give impulse to mythologemes forming; the latter, can be marked, if simplified, as good or evil ones depending on the situation and the communicative actors, as well as on general susceptibility of the community to universalized patterns of a hero, a patriot, the Motherland, Unity or an enemy, an aggressor, a traitor, a victim, Split.

Public discourse has the potential for rational control of the mythologized patterns. By means of critical reflection on a legitimate basis, if any, for the generalizations. Meanwhile, in the situation of conflict, the acute stages of identity distortion appear between the actors once regarded parts of the common identity (Slav Brothers mythologeme, coagulating Ukraine and Russia into a single space). The crisis of identity leads back to the investigation on a combat crisis in a marine by Erik Erikson, where the researcher described the symptoms going beyond the known "tiredness of war": "They [the patients] could not rely on the characteristic processes of the functioning ego by which time and space are organized and truth is tested" [Erikson, 1951:35]. The negative mythologemes produced in the informational field can easily be perceived as factual information as well, without the truth being tested, if they support the comfortable time-space distribution, regardless of critical reflection and analysis of the situation. The contradiction is rooted in the need for dignity, the state of anxiety due to the key need being impossible to get suppressed or overcome by a person.

Bystrytskyi mentions this anxiety/care modality as an existential mode of identity, it enabling defense from the values of other cultures threatening their own ones. For a person, it can make more sense than mere individual physical existence, and thus lead to fear of losing something more substantial than this mode of existence [Bystrytskyi, 2015: 70].

The mythologemes of otherness as the informational triggers of the hybrid war have been mostly viewed from the perspective of Russian-Ukrainian interactions. However, it is necessary to analyze inner otherness overcoming in Ukraine, on the cases of We-Other-Alien group shifts of IDPs status; as well as information acquisition and ignoring mechanisms having an impact on reality/counter-reality balance in law-making and practical concepts establishment. 


\section{Mythologeme-triggered otherness shift: IDP issues in Ukraine}

The practical concepts concerning, in particular, Ukraine as the community facing the hybrid war threat, have been adopted and transformed, them being an important aspect for responsibility distribution and otherness contours clarification. One of the most illustrative spheres of these liquid ever-changing practical concepts formation is correlated with the definitions of actors and territories.

In the Legal Alert of October 2017 (founded by European Union Civil Protection and Humanitarian Aid), there was reflected a set of practical concepts as follows [Ukraine: Legal Alert, 2017]:

Certain areas of Donetsk and Luhansk regions are declared as "temporarily occupied territories"

Russian Federation is recognized as an "aggressor state"

The so-called "DNR" and "LNR" are recognized as "Russian occupation administration."

The example of a direct otherness clarification during which the actor gains an explicit pejorative characterization as an aggressor is of importance in the situation of discreet informational undermining combined with the evident armed actions. The counter-reality of the double-sided aggression is based on destructive ignoring of the factual data by the party associated with aggravation of the conflict while denying the evidence.

Another counter-real situation concerns internally displaced persons (IDPs) in Ukraine. The issue of a protracted displacement has been stressed in the case studies and bulletins on Ukraine [Rushing \& Bilak, 2017; Ukraine: Area-based, 2017]. Among the recent ones there can be mentioned the case study in the OCHA Policy and Studies series; ${ }^{1}$ the UN Refugee Agency reports on legislative updates [Legislative, 2017], the legislation lacks provisions on the issue, this resulting in absence of the practical concept of protracted displacement in the legal framework having impact on IDPs, Therefore, the basic Law on rights and freedoms of IDPs shows no mechanisms correlated with the situation, ${ }^{2}$ the latter being the sphere of decision-making excluded from the actual practical concepts. Despite the fact that there has been a certain conceptual drift from the concept of forced displacement to the one of inner displacement, in the abovementioned Law, the concept becomes vague and manipulationvulnerable, as the situation influences the otherness status of the significant group. This group has been trapped in the context of prolonged disadaptation. The mythologemic OtherAlien shift-taking place in interactions between host communities and IDPs reflects deeper dimensions than expected rural/industrial regions population misunderstanding.

The mythologeme of Unity declared through mass-media is opposed to the lack of significant cultural links suggested as such. Counter-reality of the mythologeme is not evident in the situation of the current conflict as there is the group of the motivated choice of direction (for instance, the choice of migration direction: between Ukraine and the Russian Federation, in the modern hybrid war), whereas the suggested criteria of linguistic and cultural homogeneity cannot be met, even though the pro-Ukrainian choice is considered declarative in the cases of inner displacement.

The mythologeme leads to acute otherness state as an inner identity conflict, the process has been reflected in the legal texts as well.

\footnotetext{
${ }^{1}$ See [Kälin \& Entwisle, 2017; Kälin \& Entwisle, 2017a].

${ }^{2}$ See [Law of Ukraine on Provision Rights, 2017].
} 
For instance, there is an interesting amendment to Article 2 of the abovementioned Law. The words on getting the persons (IDPs) to the previously abandoned place of living and necessity of reintegration have been replaced with the phrase about creating the conditions for the voluntary return of the persons to the previously abandoned place of living or integration within the current place of living in Ukraine. Article 18 as of has also been amended to read "voluntarily, safely and with dignity return to the previously abandoned place of living or integration of IDPs" [Law of Ukraine on Amendments, 2017].

The example illustrates an otherness shift fixed documentarily throughout the period of 2015-2016, the former is the year of the Law having been issued, the latter — that of the changes being introduced. The initial set of practical concepts implied the temporary state of IDPs in the host communities, while the otherness was enhanced through the focus on return to "their" place, it is regarded as obligatory, provided the situation settle enough for the host community to initiate this return and reintegration process. The distinct demarcation between We-group and Other-group considered in terms of geographical/regional belonging clashes with the proclaimed idea of Unity. Therefore, civic society negotiations and initiatives led to the relevant and prompt changes being introduced in the practical concepts of the Law. The significant ones include the linguistic markers of previous regional segregation being eliminated, the place of living lost the obligatory identification effect. There is also the introduction of voluntary identification with geographical location and community, through the possibility of identity drift, integration to the former host community and becoming a member of the We-group.

\section{Conclusions}

The reality is reflected and moulded up to the intentions of the actors. However, the practical concepts constituting the action vocabularies of the parties involve evaluations and mythologemes having an impact on an otherness situation. Thus freedom, power, and faith construct the core of the informational speculations, them being used in the complex context of social-cultural allusions; the latter form the concept network aimed at distinguishing Wegroup from Other-group, and, due to marginalization, this otherness structure is prone to Aliengroup drift. Substitution of values with evaluations tends to have a systemic effect within the ideology-based frameworks, like those in the post-Soviet communities, while deepening the gap between We-group and Other-group, when the latter is considered inappropriate or dangerous, based on the mass-media-produced model frames. Therefore, investigation of counter-reality forming mechanisms through the hybrid war situation is to help gain a general understanding of the meaning and value distortions leading to exoticization of otherness through the practical concepts.

Thus, even though the legislation may lack the decision-making models on protracted displacement, as well as risk management adequate to the state, the practical concept of voluntary integration into the previous and transformed community or into the new one may serve as a sign of Unity mythologeme shift from counter-reality to reality.

\section{References}

Badiou, Alain. L'éthique. Essai sur la conscience du Mal. [Ethics: An Essay on the Understanding of Evil] Caen: Nous, 2003. https://ru.scribd.com/document/231356409/ L-Ethique-D-Alain-Badiou 
Bazaluk, Oleg. The Problem of War and Peace: a Historical and Philosophical Analysis. Philosophy and Cosmology, Volume 18, 2017: 85-103

Bystrytskyi, Yevhen. A Project of War: from Identity to Violence (Проект війни: від ідентичності до насильства). Philosophska dumka 15 (1), 2015: 61-74.

Danner, Stephanie. Dividuum: Machinic Capitalism and Molecular Revolution. Review on Open! Platform for Art, Culture and the Public Domain. 2015. https://www.onlineopen. org/

Dodonov, Roman, Hryhorii Kovalskyi, Vera Dodonova, and Maryna Kolinko. Polemological Paradigm of Hybrid War Research. Philosophy and Cosmology. Volume 19, 2017 :

97-109.

Erikson, Erik. Childhood and Society. London: Paladin Grafton Books, 1951. https://ru.scribd. com/doc/134563219/Erik-H-Erikson-Childhood-and-Society-BookFi-org

Kälin, Walter and Hannah Entwisle. Breaking the impasse: Reducing protracted internal displacement as a collective outcome. United Nations Office for Coordination of Humanitarian Affairs (OCHA), 2017. https://reliefweb.int/report/world/breakingimpasse-reducing-protracted-internal-displacement-collective-outcome-enukru/.

Kälin, Walter and Hannah Entwisle. Breaking the impasse: Reducing protracted internal displacement as a collective outcome - Case Study: Ukraine. United Nations Office for Coordination of Humanitarian Affairs (OCHA), 2017. https://reliefweb.int/report/ ukraine/breaking-impasse-reducing-protracted-internal-displacement-collectiveoutcome-case/.

Law of Ukraine on amendments to some laws in order to guarantee the rights and freedoms of internally displaced persons (Закон України «Про внесення змін до деяких законів України щодо посилення гарантій дотримання прав і свобод внутрішньо переміщених осіб»), 2015 (Rev. 2016). Kyiv, Visnyk Verkhovnoi Rady.

Law of Ukraine on provision rights and freedoms of internally displaced persons (Закон України «Про забезпечення прав і свобод внутрішньо переміщених осіб»), 2015 (Rev. 2017). Kyiv, Visnyk Verkhovnoi Rady.

Legislative update: Ukraine, October 2017. The UN Refugee Agency. http://www.unhcr/.

Liakh, Vitalii. Social-cultural and Theoretical Grounds of Post-modern Philosophy. Preface (Соціокультурні та теоретичні засади філософії постмодерну. Передмова). Куіv, National Academy of Sciences, 2017.

Moles, Abraham. Sociodynamique et politique d'équipement culturel dans le société urbaine [Social Dynamics and Cultural Politics in Urban Society]. Communications 69 (14), 1973: 137-149. http://www.persee.fr/doc/

Raida, Kostiantyn. Social-cultural and Theoretical Grounds of Post-modern Philosophy. Postmodern: the Problem of Philosophical Thought Transformation (Соціокультурні та теоретичні засади філософії постмодерну. Постмодерн: проблема трансформації філософського мислення). Kyiv, National Academy of Sciences, 2017.

Raunig, Gerald. Dividuum: Maschinischer Kapitalismus und molekulare Revolution. Band 1, 2015. http://www. transversal.at/.

Rushing, Elizabeth J. and Alexandra Bilak. Lives across the frontline: internal displacement in a divided Ukraine: Report. 2017. Internal Displacement Monitoring Centre. http://www.internal-displacement.org/library/expert-opinion/2017/lives-across-thefrontline-internal-displacement-in-a-divided-ukraine/ 
Ukraine: Area-based Assessment: East Luhansk Basic Service Unit Overview: REACH Report, July 2017. https://reliefweb.int/report/ukraine/ukraine-area-based-assessmenteast-luhansk-basic-service-unit-overview-july-2017-enuk/.

Ukraine: Legal Alert, October 2017. Danish Refugee Council Report. https://reliefweb.int/ report/ukraine/ukraine-legal-alert-october-2017-enruuk 